\title{
PENERAPAN PEMBELAJARAN KOOPERATIF TIPE NUMBER HEAD TOGETHER UNTUK MENINGKATKAN PRESTASI BELAJAR PKN
}

\author{
Ida Bagus Putu Gandem
}

Email: ibputugandem2018@gmail.com

\begin{abstract}
ABSTRAK
Penelitian tindakan kelas yang dilakukan di SD No. 2 Blahkiuhdi kelas IV Semester II SD No. 2 Blahkiuh Tahun Pelajaran 2015/2016bertujuan untuk mengetahui peningkatan prestasi belajar pada mata pelajaran PKN dengan penerapan model pembelajaran Kooperatif Tipe Number Head Together. Data hasil penelitian ini dikumpulkan dengan cara pemberian tes prestasi belajar. Dalam menganalisis data yang diperoleh digunakan metode analisis deskriptif. Data yang dihasilkan dari penelitian ini terdiri dari data awal, data siklus I dan data Siklus II. Dari data awal diperoleh rata-rata kelas baru mencapai nilai 69,28 dan ketuntasan belajarnya baru mencapai 25,64\%. Data ini jauh di bawah harapan mengingat KKM mata pelajaran PKN di sekolah ini adalah 76. Pada siklus I sudah terjadi peningkatan yaitu rata-rata kelasnya mencapai 74,74 dan prosentase ketuntasan belajar mencapai 53,85\%. Pada siklus II perolehan rata-rata kelas sudah mencapai 82,79 dan persentase ketuntasan belajarnya sudah mencapai $97,44 \%$. Data pada Siklus II ini sudah sesuai harapan akibat penggunaan model pembelajaran yang sifatnya konstruktivis. Simpulan yang diperoleh adalah model pembelajaran Kooperatif Tipe Number Head Together dapat meningkatkan prestasi belajar PKN siswa.
\end{abstract}

Kata kunci: Model Pembelajaran Kooperatif Tipe Number Head Together, Prestasi Belajar

\begin{abstract}
Classroom action research conducted in SD No. 2 Blahkiuh in class IV Semester II SD No. 2 Blahkiuh Academic Year 2015/2016 aims to determine the improvement of learning achievement in PKN subjects by applying the Cooperative learning model Type Number Head Together. The data of this study were collected by giving the achievement test. In analyzing the data obtained used descriptive analysis method. The data generated from this research consist of preliminary data, cycle data I and Cycle II data. From the preliminary data, the average new class reached 69.28 and the learning completeness only reached $25.64 \%$. This data is far below expectations considering that the PKN PKM in this school is 76. In the first cycle there has been an increase, namely the average class reaches 74.74 and the percentage of learning completeness reaches $53.85 \%$. In the second cycle the acquisition of the average class had reached 82.79 and the percentage of mastery learning had reached $97.44 \%$. The data in Cycle II is in line with expectations due to the use of constructivist learning models. The conclusions obtained are the Cooperative Type Number Head Together learning model can improve students' PKN learning achievement.
\end{abstract}

Keywords: Cooperative Learning Model Type Head Together Number,Learning Achievement 


\section{PENDAHULUAN}

Tugas seorang guru dalam proses pembelajaran adalah memberikan bantuan secara berkelanjutan kepada siswanya untuk mendapatkan informasi, ide dan gagasan, keterampilan-keterampilan, nilai-nilai, dan cara-cara berpikir sistematis dan terstruktur untuk dapat membangun pemahaman baru dengan bekal pengetahuan dan pemahaman sebelumnya. Tugas lainnya yang harus dilakukan guru yaitu memberikan bimbingan kepada siswa bagaimana belajar dengan sebenarnya, memecahkan persoalan yang dihadapi untuk persiapan mengisi masa depan mereka.

Sebagai wujud tanggung jawab guru selaku ujung tombak pendidikan, dibutuhkan upaya nyata dalam memperbaiki mutu pendidikan utamanya pada mata pelajaran PKN Alternatif tindakan yang dilakukan guru adalah perbaikan proses pembelajaran menggunakan model pembelajaran Kooperatif Tipe Number Head Togetheryang lebih menitikberatkan pada partisipasi dan keaktifan siswa dalam proses pembelajaran. Penggunaan model/metode ini didasarkan pada pemikiran bahwa setiap orang memiliki rasa ingin tahu yang tinggi jika dikenalkan pada suatu yang baru dan menarik. Yang harus dilakukan adalah proses penyampaian yang dilakukan harus dapat mengundang keinginan siswa untuk dapat melakukannya sehingga tercapai kepuasan diri karenanya.

Pembelajaran dengan menerapkan model pembelajaran Kooperatif Tipe Number Head Togethermerupakan salah satu model, strategi, dan pendekatan pembelajaran khususnya menyangkut keterampilan guru dalam merancang, mengembangkan, dan mengelola sistem pembelajaran sehingga guru mampu menciptakan suasana pembelajaran yang efektif dan menggairahkan. Sehubungan dengan materi yang akan disampaikan pada mata pelajaran PKN menyangkut masalah rendahnyaprestasibelajar PKN siswa maka model pembelajaran Kooperatif Tipe Number Head Togethertersebutlah yang dipandang efektif dalam pembelajaran sebagai solusi dalam mengatasi masalah rendahnya prestasi belajar siswa kelas IV Semester II SD No. 2 Blahkiuh Tahun Pelajaran 2015/2016yang disusun dengan judul "Penerapan Model Pembelajaran Kooperatif Tipe Number Head Together Untuk Meningkatkan Prestasi Belajar PKN Siswa Kelas IVSemester II SD No. 2 Blahkiuh Tahun Pelajaran 2015/2016".

Rumusanmasalahdalampenelitianinia dalah :Apakahpenerapan model pembelajarankooperatiftipeNumber Head Togetherdapatmeningkatkanprestasibelajar PKN siswakelas IV Semester II SD No. 2 Blahkiuh Tahun Pelajaran 2015/2016 ?

Tujuanpenelitianiniadalah

:Untukmengetahui

peningkatanprestasibelajarPKNsiswakelas

IV Semester II SD No. 2 Blahkiuh Tahun Pelajaran 2015/2016denganpenerapan model pembelajarankooperatiftipeNumber Head Together.

Penelitian ini diharapkan akan bermanfaat sebagai acuan dalam memperkaya teori dalam rangka peningkatan kompetensi guru. Sedangkan secara praktis penelitian ini diharapkan bermanfaat:Bagi siswa, dapat meningkatkan prestasi belajar PKN dengan penerapanmodel pembelajaran Kooperatif Tipe Number Head Together.Bagi guru, menambah wawasan untuk meningkatkan profesionalisme guru dengan mengadakan berbagai kegiatan ilmiah berupa penelitian dan penulisan karya ilmiah.Bagi sekolah, khususnya SD No. 2 Blahkiuh sebagai informasi yang berharga bagi teman-teman guru, kepala sekolah dalam rangka 
bersama-sama memperbaiki kualitas pembelajaran dan mutu pendidikan.

Model

pembelajarankooperatiftipeNumber Head

Togetherdikembangkanoleh Spencer Kagan (1992).

Model

pembelajaraninimemberikankesempatanpad asiswauntuksalingmembagikan ide-ide danmempertimbangkanjawaban yang paling tepat. Selainitu, model pembelajaraninijugamendorongsiswauntuk meningkatkansemangatkerjasamamereka. Tehnikinibisadigunakanuntuksemuamatape lajarandanuntuksemuatingkatanusiasiswa. $N$ umbered Head Together atau disingkat NHT. model pembelajaran kooperatif tipe Number Head Together adalah suatu model pembelajaran yang lebih mengedepankan kepada aktivitas siswa dalam mencari, mengolah, dan melaporkan informasi dari berbagai sumber yang akhirnya dipresentasikan di depan kelas (Rahayu, 2009).

Model pembelajaran kooperatif tipe Number Head Together adalah bagian dari model pembelajaran kooperatif struktural, yang menekankan pada struktur-struktur khusus yang dirancang untuk mempengaruhi pola interaksi siswa. Struktur Kagan menghendaki agar para siswa bekerja saling bergantung pada kelompok-kelompok kecil secara kooperatif. Struktur tersebut dikembangkan sebagai bahan alternatif dari sruktur kelas tradisional seperti mangacungkan tangan terlebih dahulu untuk kemudian ditunjuk oleh guru untuk menjawab pertanyaan yang telah dilontarkan. Suasana seperti ini menimbulkan kegaduhan dalam kelas, karena para siswa saling berebut dalam mendapatkan kesempatan untuk menjawab pertanyaan peneliti (Tryana, 2008).

Model pembelajaran kooperatif tipe Number Head Together merupakan salah satu tipe pembelajaran kooperatif yang menekankan pada struktur khusus yang dirancang untuk mempengaruhi pola interaksi siswa dan memiliki tujuan untuk meningkatkan penguasaan akademik. Tipe ini dikembangkan oleh Kagan dalam Ibrahim (2000) dengan melibatkan para siswa dalam menelaah bahan yang tercakup dalam suatu pelajaran dan mengecek pemahaman mereka terhadap isi pelajaran tersebut.

Di bawah ini akan dikemukakan beberapa pengertian prestasi dan belajar menurut para ahli.Prestasi belajar berasal dari kata "prestasi" dan "belajar". Prestasi berarti hasil yang telah dicapai sedangkan belajar adalah berusaha memperoleh ilmu (Depdiknas, 2011: 4). Selanjutnya Menurut Bustalin (2004:11) bahwa"Prestasi belajar siswa merupakan hasil yang diperoleh dari proses belajar mengajar. Prestasi belajar siswa adalah perubahan dalam hal kecakapan tingkah laku ataupun kemampuan yang dapat bertambah selama beberapa waktu dan tidak disebabkan oleh proses pertumbuhan, tetapi adanya situasi belajar, perwujudan dalam bentuk hasil proses belajar tersebut dapat berupa pemecahan lisan atau tulisan, dan ketrampilan serta pemecahan masalah yang langsung dapat diukur atau dinilai dengan menggunakan tes-tes yang berstandar."

Sutratinah Tirtonegoro (2001: 43) menyatakan bahwa, "Prestasi belajar adalah penilaian hasil usaha kegiatan belajar mengajar yang dalam bentuk simbol, angka, huruf, atau kalimat yang dapat mencerminkan hasil usaha yang sudah dicapai oleh siswa dalam periode tertentu". Sedangkan menurut Sunarwan (1991) prestasi belajar merupakan evaluasi hasil dari suatu poses belajar atassejumlah materi pelajaran. Evaluasi atas proses belajar pada kurun waktu tertentuini didasarkan suatu 
system penilaian tertentu, yang biasanya dinyatakan dalam bentuk laporan tertentu misalnya pada nilai rapor. Dalam evaluasi tersebutterkandung penilaian ataupun pengukuran terhadap sejumlah tingkat kemampuanaktual yang berupa keberhasilan dalam penguasaan terhadap sejumlah ilmu pengetahuan, dan juga perubahan atas sikap dan keterampilan sebagai akibatlangsung dari proses belajar tersebut.

Selanjutnya menurut Peter Salim (1995:190) prestasi belajar adalah penguasaan pengetahuan terhadap mata pelajaran yang dibuktikan melalui hasil tes yaitu penguasaan pengetahuan atau keterampilan yang dikembangkan oleh mata pelajaran, lazimnya ditunjukkan dengan nilai tes atau angka nilai yang diberikan oleh guru.

Berdasarkan pendapat dari beberapa ahli tersebut maka. dapat disimpulkan bahwa prestasi belajar adalah suatu indeks kemampuan seseorang terutama kognitifnya dalam menyerap suatu ilmu yang kemudian dapat menunjukkan suatu kemajuan atau kelambatan dalam menerima, memahami dan menguasai materi yang dikuasai dan dinyatakan dalam nilai-nilai rapor.

Berdasarkanteoripembelajarandanhas il yang dapat dicapai dalam penerapannya, maka

penelitidapatmenyusunhipotesistindakanseb agaiberikut:Jika model pembelajarankooperatiftipeNumber Head Togetherditerapkansesuaiteoriahlimakamen ingkatkanprestasibelajar PKNsiswakelasIV Semester II SD No. 2 Blahkiuh Tahun Pelajaran 2015/2016.

Sebagai upaya untuk meningkatkan prestasi belajar siswa, guru melakukan penelitian di SD No. 2 Blahkiuh.Lingkungansekolahinisangatsejuk karena di sekitar areal sekolahmasihterdapatperkebunan

Rancanganpenelitiantindakandalampe nelitianinidisampaikanolehSuharrsimi Arikuntosepertiterlihatpadagambarberikut

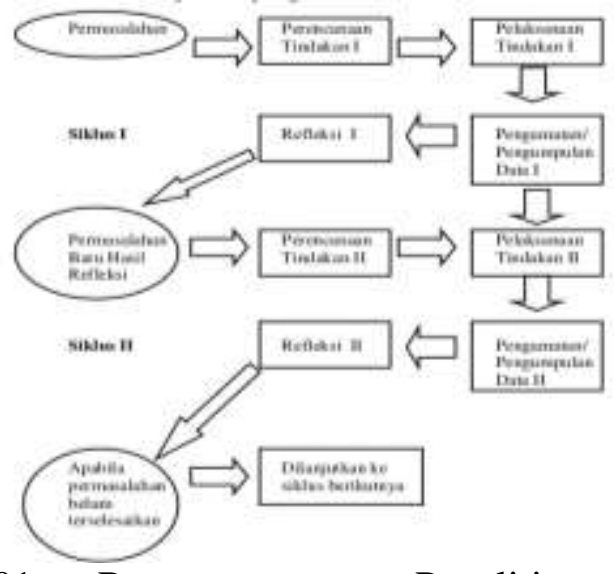

Gambar 01. Rancangan Penelitian Tindakan Kelas (dalam Suharsimi Arikunto, Suhardjono, Supardi, 2007: 74)

Subjekpenelitianiniadalahsemuasiswa kelas IV Semester II SD No. 2 Blahkiuh Tahun Pelajaran 2015/2016. Penelitian ini dilakukan dari bulan Januari sampai bulan April 2016. Teknikpengumpulan data merupakancarakerjadalampenelitianuntukm emperoleh data atauketerangan-keterangandalamkegiatanse suaidengankenyataan. Teknikpengumpulan data yang digunakandalampenelitiantindakankelasinia dalahobservasidantes prestasi belajar.Metode yang digunakan untuk menganalisis data hasil penelitian ini adalah metode deskriptif kuantitatif. Data kuantitatif dianalisis dengan mencari mean, median, modus, membuat interval kelas dan melakukan penyajian dalam bentuk tabel dan grafik.

Indikator keberhasilan yang diusulkan dalam penelitian ini pada siklus I mencapai nilai rata-rata 76 dan pada siklus II mencapai nilai rata-rata 76 atau lebih dengan ketuntasan belajar minimal $80 \%$. 


\section{HASIL PENELITIAN DAN PEMBAHASAN}

\section{Deskripsi Awal}

Hasil obervasi awal menunjukkan, rendahnya prestasi belajar yang dicapai peserta didik di kelas IV Semester II SD No. 2 Blahkiuh Tahun Pelajaran 2015/2016. Dari kegiatan awal diperoleh hanya 10 orang siswa $(25,64 \%)$ yang memperoleh nilai sesuai dan diatas KKM. Ketuntasan belajar kelas ini pada awalnya baru mencapai $25,64 \%$, masih banyak siswa yang belum tuntas yaitu 29 orang dengan prosentase $74,36 \%$. Data tersebut menunjukkan bahwa kemampuan peserta didik dalam menerpa ilmu pada mata pelajaran PKN masih sangat rendah.

\section{Deskripsi Siklus I}

\section{a. Perencanaan I}

Peneliti telah giat membuat perencanaan dari kegiatan penelitian ini. hal-hal yang menjadi perencanaan adalah Menyusun jadwal untuk pelaksanaan.Menyusun rencana kegiatan. Berkonsultasi dengan teman-teman guru, membicarakan alat-alat peraga, bahan-bahan yang bisa membantu peningkatan perkembangan

siswa.Merencanakan model pembelajaran yang paling tepat diinginkan dalam pembelajaran.

Dan membuat bahan-bahan pendukung pembelajaran.Merancang skenario pembelajaran. Menyusun format penilaian.

\section{b. Pelaksanaan I}

Pelaksanaan penelitian ini telah didahului dengan penyusunan perencanaan. Perencanaan yang telah disusun dengan baik menjadi dasar dalam melaksanakan penelitian ini. Untuk itu peneliti melaksanakan dengan menerapkan langkah-langkah model pembelajaranKooperatif Tipe Number Head Together.

\section{c. Observasi I}

Hasil observasi dari pelaksanaan pembelajaran pada siklus I menunjukkan, dari 39orang siswa kelas IV Semester II SD No. 2 Blahkiuh Tahun Pelajaran 2015/2016yang diteliti sudah ada 21 orang siswa yang memperoleh penilaian di atas dan sesuai KKM serta ada 18 orang siswa memperoleh nilai dibawah KKM. Rata-rata siklus I baru mencapai 74,74 dengan presentase ketuntasan $53,85 \%$.

\section{d. Refleksi I}

Sesuai pendapat ahli di atas, maka dalam refleksi ini disampaikan analisis, sintesis dan penilaian seperti berikut:

\section{Analisis}

Hasil yang diperoleh dari penilaian prestasi belajar siswa pada siklus I dapat dibuat dalam deskripsi kuantitatif seperti berikut: dari 39 orang siswa yang diteliti ada 11 orang $(28,20 \%)$ yang memperoleh penilaian diatas KKM dimana mereka sudah mampu menerpa ilmu sesuai harapan. Ada 10 orang $(25,65 \%)$ yang memperoleh 
penilaian sama dengan KKM yang artinya bahwa mereka juga sudah mampu menguasai materi sesuai harapan. Untuk siswa-siswa tersebut sesuai kategori penilaian dari Depdiknas, mereka sudah berkembang sesuai indikator yang disampaikan di Bab III. Sedangkan yang lain yang jumlahnya 18 orang $(46,15 \%)$ masih belum mencapai KKM pada mata pelajaran PKN di sekolah ini. Untukanalisiskuantitatifd isampaikansebagaiberikut :

1. Rata-rata

(mean) dihitung

dengan: $\frac{\text { Jumla } h \text { nilai }}{\text { Jumla } h \text { siswa }}=$ $\frac{2915}{39}=74,74 \%$

2. Median (titik tengahnya) dicari dengan mengurut data/nilai siswa dari yang terkecil sampai terbesar. Setelah diurut apabila jumlah data ganjil maka mediannya adalah data yang ditengah. Kalau jumlahnya genap maka dua data yang di tengah dijumlahkan dibagi 2 (dua). Untuk median yang diperoleh dari data siklus I dengan menggunakan cara tersebut adalah: 76 .

3. Modus (angka yang paling banyak/paling seringmuncul) setelahdiasccending/diur utangkatersebutadalah:

76.
4. Untuk persiapan penyajian dalam bentuk grafik maka hal-hal berikut dihitung terlebih dahulu.

1. Banyak kelas $(\mathrm{K})=1$ $+3,3 \times \log (\mathrm{N})=1+$ $3,3 \times \log 39=1+$ $(3,3 \times 1,59)=1+5,24$ $=6,24=7$

2. Rentang kelas $(r)=$ skor maksimum skor minimum $=86-$ $68=18$

3. Panjang kelas interval (i) $=\frac{r}{K}=\frac{18}{7}$ $=2,57=3$

4. Tabel 01. Data Kelas Interval Siklus I

\begin{tabular}{ccccc}
\hline $\begin{array}{c}\text { No } \\
\text { ut }\end{array}$ & $\begin{array}{c}\text { Inter } \\
\text { val }\end{array}$ & $\begin{array}{c}\text { NilaiTen } \\
\text { gah }\end{array}$ & $\begin{array}{c}\text { FrekuensiA } \\
\text { bsolut }\end{array}$ & $\begin{array}{c}\text { FrekuensiR } \\
\text { elatif }\end{array}$ \\
\hline 1 & $\begin{array}{c}68- \\
64\end{array}$ & 69.0 & 10 & 25.64 \\
\hline 2 & $\begin{array}{c}71- \\
68\end{array}$ & 72.0 & 7 & 17.95 \\
\hline 3 & $\begin{array}{c}74- \\
72\end{array}$ & 75.0 & 11 & 28.21 \\
\hline 4 & $\begin{array}{c}77- \\
76\end{array}$ & 78.0 & 5 & 12.82 \\
\hline 5 & $\begin{array}{c}80- \\
80\end{array}$ & 81.0 & 1 & 2.56 \\
\hline 6 & $\begin{array}{c}83- \\
84\end{array}$ & 84.0 & 2 & 5.13 \\
\hline 7 & $86-$ & 87.0 & 3 & 7.69 \\
\hline & 88 & & 39 & 100.00 \\
\hline
\end{tabular}

5. Penyajiandalambentukgrafik/histogram 


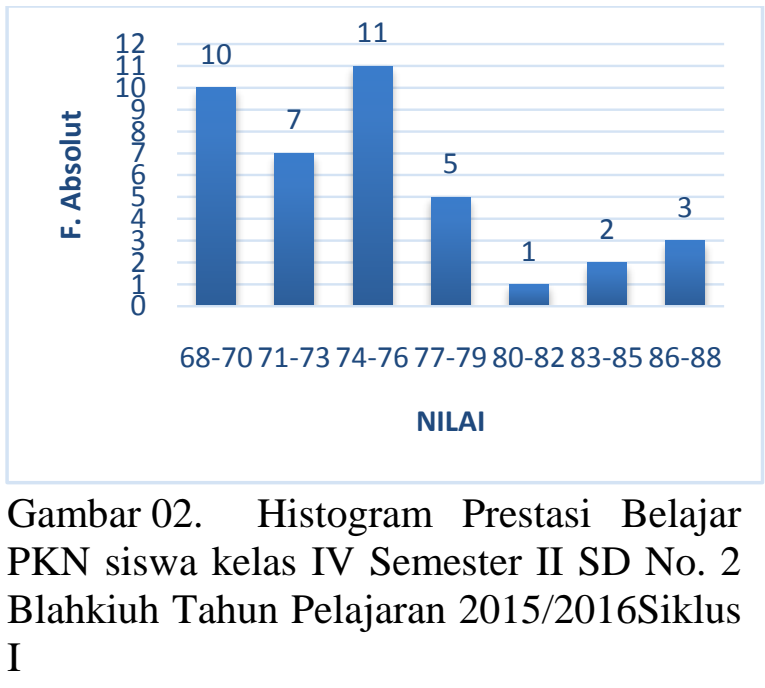

\section{Sintesis}

Memperhatikan pendapat para ahli pendidikan yang telah disampaikan di awal penulisan refleksi, bahwa dalam refleksi dilakukan analisis, sintesis dan penilaian/evaluasi, sehingga pada bagian ini perlu disajikan hal-hal tersebut. Sintesis artinya campuran berbagai pengertian sehingga merupakan kesatuan yang selaras (Kamus Besar Bahasa Indonesia: 713). Sintesis Bahasa InggrisnyaadalahSynthesis yang artinyathe putting of parts together for a whole (Webster's New American Dictionary: 1016). Apabila pengertian dalam Bahasa Inggris tersebut dijadikan Bahasa Indonesia, maka Sintesis berarti menaruh semua bagian-bagian menjadi satu. Artinya semua data yang sudah dianalisis, baik proses pembelajaran, keaktifan belajar maupun hasil yang diperoleh dari prestasi belajar disatukan dan dicoba diberi gambaran.

Perkembangan bahasa siswa pada Siklus I ini adalah dari 39 orangsiswa yang diteliti ternyata hasilnya belum sesuai dengan harapan. Dari perkembangan tersebut diketahui adanya kekurangan yaitu pada pelaksanaan proses belajar mengajar di mana para siswa belum semuanya aktif belajar, mereka masih sering menunggu perintah-perintah guru, penugasan, hanya 21 orang siswa yang sudah mampu melakukan apa yang mesti dilakukan. Dari semua data yang sudah diperoleh tersebut dapat diberikan sintesis bahwa masih sangat sedikit siswa yang mampu mencapai tingkat keberhasilan yang diharapkan.

\section{Deskripsi Siklus II}

\section{a. Perencanaan II}

Peneliti telah giat membuat perencanaan dari kegiatan penelitian siklus II. hal-hal yang menjadi perencanaan adalah Menyusun jadwal untuk pelaksanaan.Menyusun rencana kegiatan. Berkonsultasi dengan teman-teman guru, membicarakan alat-alat peraga, bahan-bahan yang bisa membantu peningkatan perkembangan

siswa.Merencanakan model pembelajaran yang paling tepat diinginkan dalam pembelajaran.

Dan membuat bahan-bahan pendukung

pembelajaran.Merancang skenario pembelajaran. Menyusun format penilaian.

\section{b. Pelaksanaan II}

Pelaksanaan penelitian ini telah didahului dengan penyusunan perencanaan. Perencanaan yang telah disusun dengan baik menjadi dasar dalam melaksanakan penelitian ini. Untuk itu peneliti melaksanakan dengan menerapkan langkah-langkah model pembelajaranKooperatif Tipe Number Head Together.

\section{c. Pengamatan/Observasi II}

Hasil observasi dari pelaksanaan pembelajaran pada siklus II 
menunjukkan, dari 39orang siswa kelas IV Semester II SD No. 2 Blahkiuh Tahun Pelajaran 2015/2016yang diteliti sudah ada 38 orang siswa yang memperoleh penilaian di atas KKM dan hanya 1 orang siswa memperoleh nilai dibawah KKM. Rata-rata siklus II sudah mencapai 82,79 dengan presentase ketuntasan $97,44 \%$.

\section{d. Refleksi II}

Pendapat ahli yang sudah disampaikan pada refleksi Siklus I dijadikan dasar untuk menulis analisis, sintesis dan evaluasi siklus II agar tidak ngawur dalam penulisan refleksi.

\section{Analisis}

Pendapat-pendapat ahli maupun

pandangan-pandangan yang dikemukakan oleh Depdiknas yang telah disampaikan pada analisis di Siklus I tentang cara menulis analisis deskriptif penulis jadikan dasar menulis analisis berikut.

Hasil yang diperoleh dari penilaian tes prestasi belajar dapat dijelaskan: dari 39 orang siswa yang diteliti, 38 orang siswa atau $97,44 \%$ siswa sudah mampu mencapai nilai-nilai batas KKM ke atas. Gambaran yang bisa disampaikan adalah bahwa semua siswa senang dan antusias cara pembelajaran yang dilakukan guru, cara tersebut telah mampu menjadikan siswa aktif, giat bekerja dan belajar. Dari analisis kualitatif sudah disampaikan secara singkat, selanjutnya diberikan analisis kuantitatifnya menggunakan data yang diperoleh adalah dalam bentuk angka sebagai berikut :

1. Rata-rata (mean) dihitung

dengan: $\frac{\text { Jumla } h \text { nilai }}{\text { Jumla } h \text { siswa }}=$ $\frac{3229}{39}=82,79$

2. Median (titik tengahnya) dicari dengan mengurut data/nilai siswa dari yang terkecil sampai terbesar. Setelah diurut apabila jumlah data ganjil maka mediannya adalah data yang ditengah. Kalau jumlahnya genap maka dua data yang di tengah dijumlahkan dibagi 2 (dua). Untuk median yang diperoleh dari data siklus I dengan menggunakan cara tersebut adalah: 83 .

3. Modus (angka yang paling banyak/paling seringmuncul) setelahdiasccending/diur ut. Angkatersebutadalah: 84.

4. Untuk persiapan penyajian dalam bentuk grafik maka hal-hal berikut dihitung terlebih dahulu.

1. Banyak kelas $(\mathrm{K})=1$ $+3,3 \times \log (\mathrm{N})=1+$ $3,3 \times \log 39=1+$ $(3,3 \times 1,59)=1+5,24$ $=6,24=7$ 
2. Rentang kelas (r) =skor maksimum skor minimum $=93-$ $75=18$

3. Panjang interval kelas $\frac{r}{K}=\frac{18}{7}=2,57=3$

4. Tabel 02. Data Kelas Interval Siklus II

\begin{tabular}{ccccc}
\hline $\begin{array}{c}\text { No } \\
\text { ut }\end{array}$ & $\begin{array}{c}\text { Inter } \\
\text { val }\end{array}$ & $\begin{array}{c}\text { NilaiTen } \\
\text { gah }\end{array}$ & $\begin{array}{c}\text { FrekuensiA } \\
\text { bsolut }\end{array}$ & $\begin{array}{c}\text { FrekuensiR } \\
\text { elatif }\end{array}$ \\
\hline $\begin{array}{c}75- \\
77\end{array}$ & 76.0 & 7 & 17.95 \\
\hline 2 & $\begin{array}{c}78- \\
80\end{array}$ & 79.0 & 9 & 23.08 \\
\hline 3 & $\begin{array}{c}81- \\
83\end{array}$ & 82.0 & 6 & 15.38 \\
\hline 4 & $\begin{array}{c}84- \\
86\end{array}$ & 85.0 & 6 & 15.38 \\
\hline 5 & $\begin{array}{c}87- \\
89\end{array}$ & 88.0 & 5 & 12.82 \\
\hline 6 & $90-$ & 91.0 & 4 & 10.26 \\
\hline 7 & $93-$ & 94.0 & 2 & 5.13 \\
\hline & 95 & & 39 & 100.00 \\
\hline
\end{tabular}

5. Penyajiandalambentukgrafik/histogram

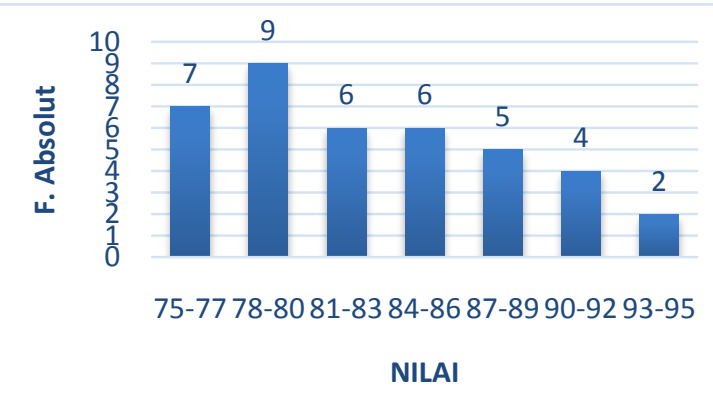

Gambar 03. Histogram Prestasi Belajar PKN siswakelas IV Semester II SD No. 2 Blahkiuh Tahun Pelajaran 2015/2016Siklus II

\section{Sintesis}

Sintesis artinya campuran berbagai pengertian sehingga merupakan kesatuan yang selaras atau menaruh semua bagian-bagian menjadi satu. Artinya semua data yang sudah dianalisis, baik proses pembelajaran, keaktifan belajar maupun hasil yang diperoleh dari prestasi belajar disatukan dan dicoba diberi gambaran.

Perkembangan bahasa siswa pada Siklus II ini adalah dari 39 orang siswa yang diteliti ternyata hasilnya sudah sesuai dengan harapan. Dari perkembangan tersebut diketahui semua siswa sudah sangat mampu untuk melakukan tanpa dibantu. Dari semua data yang sudah diperoleh tersebut dapat diberikan sintesis bahwa semua siswa sudah mampu mencapai prestasi sesuai harapan, artinya proses pembelajaran sudah berjalan baik, inovasi sudah diupayakan, validasi terhadap instrumen sudah dilakukan, triangulasi juga sudah dilakukan, keaktifan siswa cukup baik. Dari semua pendekatan data atas tindakan yang dilakukan pada siklus II dapat diintepretasikan bahwa semua indikator yang diharapkan dicapai oleh siswa-siswa SD No. 2 Blahkiuh sudah mampu dicapai.

\section{Penilaian Siklus II}

Penilaian terhadap seluruh kegiatan penelitian yang sudah dilakukan pada Siklus II adalah proses belajar mengajar sudah berjalan lancar, semua kekurangan-kekurangan yang ada sudah diperbaiki pada siklus ini, sehingga tidak ada yang masih perlu diragukan bahwa hasil yang diperoleh pada Siklus II ini membuktikan bahwa penelitian ini tidak perlu dilanjutkan lagi ke siklus berikutnya karena hasil yang diperoleh sudah maksimal yaitu 38 orang siswa $(97,44 \%)$ siswa sudah berhasil dan rata-rata kelas sudah jauh diatas KKM yang dituntut.

\section{Pembahasan}

Deskripsi hasil pra siklus sudah disampaikan pada latar belakang masalah sehingga pembahasan ini dimulai dengan 
hasil pada siklus I.Bagian pembahasan merupakan ruang bagi peneliti untuk menggambarkan hasil-hasil yang diperoleh selama pelaksanaan penelitian. Hal-hal yang perlu diperhatikan dalam pembahasan data kualitatif adalah: kelemahan-kelemahan yang ada, kelebihan-kelebihan, perubahan-perubahan, kemajuan-kemajuan, efketivitas waktu, keaktifan yang dilakukan, konstruksi, kontribusi, diskripsi fakta, pengecekan validitas internal dan validitas eksternal, identifikasi masalah, faktor-faktor yang berpengaruh.

Pembahasan hasil yang diperoleh dari tes prestasi belajar siklus I

Nilai rata-rata siswa di siklus I sebesar 74,74 menunjukkan bahwa siswa telah menguasai materi yang diajarkan walaupun belum begitu sempurna. Hasil ini menunjukkan peningkatan kemampuan siswa menguasai mata pelajaran PKN jika dibandingkan dengan nilai awal siswa sesuai data yang sudah disampaikan yaitu 69,28. Tes prestasi belajar yang dilakukan telah menemukan efek bahwa penggunaan metode tertentu akan berpengaruh terhadap prestasi belajar siswa yang dalam hal ini adalah model pembelajaran Kooperatif Tipe Number Head Together.

Mata pelajaran PKN menitikberatkan pembelajaran pada aspek kognitif, afektif, dan psikomotor sebagai pedoman prilaku kehidupan sehari-hari siswa. Penggunaan metode ini dapat membantu siswa untuk berkreasi, bertukar pikiran, mengeluarkan pendapat, bertanya, berargumentasi, bertukar informasi dan memecahkan masalah yang ada. Hal inilah yang membuat siswa berpikir lebih tajam, lebih kreatif dan kritis sehingga mampu untuk memecahkan masalah-masalah yang kompleks dan efek selanjutnya adalah para siswa akan dapat memahami dan meresapi mata pelajaran PKN lebih jauh.
Kekurangan-kekurangan yang ada pada siklus I seperti belum maksimalnya diskusi yang dilakukan peserta didik akibat ada peserta didik yang mendominasi waktu dipecahkan dengan memberi penekanan agar tidak ada siswa yang mendominasi waktu dan kekurangan terhadap keaktifan belajar dipecahkan dengan menggiatkan pemberian pertanyaan-pertanyaan. Dengan begitu giat peneliti sebagai guru melakukan tindakan namun masih ada kendala yang perlu dibahas yaitu prestasi belajar yang dicapai pada siklus I ini belum memenuhi harapan sesuai dengan kriteria keberhasilan penelitian yang diusulkan pada mata pelajaran PKN di sekolah ini yaitu sesuai KKM 76.

Pembahasan hasil yang diperoleh pada siklus II

Hasil yang diperoleh dari pelaksanaan proses pembelajaran di siklus II menunjukkan bahwa kemampuan siswa dalam mengikuti pelajaran sudah cukup baik. Ini terbukti dari rata-rata nilai siswa mencapai 82,79. Hasil ini menunjukkan bahwa model pembelajaran Kooperatif Tipe Number Head Togethertelah berhasil meningkatkan kemampuan siswa menempa ilmu sesuai harapan. Model pembelajaran Kooperatif Tipe Number Head Togethermerupakan model yang cocok bagi siswa apabila guru menginginkan peserta didiknya mampu meningkatkan kemampuan untuk berkreasi, berargumentasi, mengeluarkan pendapat secara lugas, bertukar pikiran, mengingat penggunaan metode ini adalah untuk mengarahkan agar siswa antusias menerima pelajaran.

Hal pokok yang perlu menjadi perhatian yaitu hasil penelitian ini ternyata telah memberi efek utama bahwa model yang diterapkan dalam proses pembelajaran berpengaruh secara signifikan terhadap 
prestasi belajar siswa. Temuan ini membuktikan bahwa guru sudah tepat memilih metode dalam melaksanakan proses pembelajaran karena pemilihan metode merupakan hal yang tidak boleh dikesampingkan.

Dari nilai yang diperoleh siswa, masih tersisa 1 orang siswa mendapat nilai di bawah KKM, sedangkan 38 orang siswa lainnya sudah memperoleh nilai memenuhi KKM yang ditetapkan. Dari perbandingan nilai ini sudah dapat dibuktikan bahwa prestasi belajar siswa dapat ditingkatkan dengan penggunaan model pembelajaran ini. Walaupun penelitian ini sudah bisa dikatakan berhasil, namun pada saat-saat peneliti mengajar di kelas selanjutnya, cara ini akan terus dicobakan termasuk di kelas-kelas lain yang peneliti ajar.

Setelah dibandingkan nilai awal, nilai siklus I dan nilai siklus II, terjadi kenaikan yang signifikan, yaitu dari rata-rata nilai awal adalah 69,28 naik di siklus I menjadi 74,74 dan di siklus II naik menjadi 82,79. Kenaikan ini tidak bisa dipandang sebelah mata karena kenaikan nilai ini adalah dari upaya-upaya yang maksimal yang dilaksanakan peneliti demi peningkatan mutu pendidikan dan kemajuan pendidikan khususnya di SD No. 2 Blahkiuh.

\section{PENUTUP}

\section{Simpulan}

Pelaksanaankegiatanpenelitian, sesuai dengan data hasil penelitian dan analisis deskriptif yang telah dilaksanakan memberikan dibuktikandengan data:

- Dari data awal ada 29 orang siswa mendapat nilai dibawah KKM dan pada siklus I menurun menjadi 18 orang siswa dan siklus II hanya 1 orang siswa mendapat nilai di bawah KKM.
- Nilai rata-rata awal 69,28 naik menjadi 74,74 pada siklus I dan pada siklus II naik menjadi 82,79.

- Dari data awal siswa yang tuntas hanya 10 orang sedangkan pada siklus I menjadi lebih banyak yaitu 21 orang siswa dan pada siklus II menjadi cukup banyak yaitu 38 orang siswa.

- Presentasi ketuntasan belajar awal yang baru mencapai 25,64\%,pada siklus I meningkat menjadi 53,85\%dan pada siklus II naik menjadi $97,44 \%$.

Jadi simpulan yang peneliti dapat sampaikan adalah penerapan model pembelajaran Kooperatif Tipe Number Head Together dapat meningkatkan prestasi belajar PKN siswa kelas IV Semester II SD No. 2 Blahkiuh Tahun Pelajaran 2015/2016.

\section{Saran}

Bukti kebrhasilan penelitian yang telah disampaikan menjadi pedoman peneliti untuk menyampaikan saran sebagai berikut Kepada teman guru pengajar mata pelajaran PKN disarankan untuk mencoba model pembelajaran Kooperatif Tipe Number Head Together.Kepada kepala sekolah disarankan untuk memberi penekanan agar guru mau melaksanakan pembelajaran dengan langkah-langkah model yang sudah diteliti.Kepada pengawas sekolah agar dalam membina guru agar menyarankanuntukmenggunakanmodel pembelajaran Kooperatif Tipe Number Head Together.Selanjutnya untuk adanya penguatan-penguatan, diharapkan bagi peneliti lain untuk melakukan penelitian lanjutan guna verifikasi data hasil penelitian. 


\section{DAFTAR PUSTAKA}

Arikunto, S; Suhardjono; Supardi. (2007). Penelitian Tindakan Kelas. Jakarta: PT Bumi Aksara.

Bustalin. (2004). Analisis prestasi belajar dalam pengajaran remedial pada mata pelajaran IPS Ekonomi Kelas Ii Semester I SLTP Negeri I Linggang Bigung kabupaten Kutai Barat.

http://www.geocities.com/guruval ah/penelitian5.html.23

Depdiknas. (2011). Membimbing Guru dalam Penelitian Tindakan Kelas. Jakarta: Pusat Pengembangan Tenaga Kependidikan Badan Pengembangan Sumber Daya Manusia Pendidikan dan Menjaminan Mutu Pendidikan.

Ibrahim, M dkk. (2000). Pembelajaran Kooperatif. Surabaya: University
Press.

Peter S, Yeni S. (1995). Kamus Indonesia Kontemporer. Jakarta: Modern English Press.

Rahayu, S. (2009). Numbered Head Together. [Online]. Tersedia: http://pelawiselatan.blogspot.com/ 2009/03/numbered-head-together. html.

Sunarwan, (1991). Pendekatan Sistem dalam Pendidikan. Sebelas maret University Press, Surakarta.

Sutratinah T. (2001). Penelitian Hasil Belajar Mengajar. Surabaya: Usaha Nasional.

Tryana, A. (2008). Penerapan Model Pembelajaran Kooperatif Numbered Heads Together (NHT). Tersedia: http://iqbalali.com/2010/01/03/nht -numbered-head-togethr. 